\title{
National Physical Education Standards: Level of Physical Fitness Male Student Primary School in Malaysia
}

\author{
Ahmad Hashim (Corresponding author) \\ Department of Exercise Science, Faculty of Sport Science and Coaching \\ Sultan Idris Education University \\ Tanjong Malim, Perak, Malaysia \\ Tel: 60-124-095-658Ｅ-mail: ahmad@fsskj.upsi.edu.my
}

Mohd. Sani Madon

Department of Exercise Science, Faculty of Sport Science and Coaching

Sultan Idris Education University

Tanjong Malim, Perak, Malaysia

Tel: 60-192-121-278Ｅ-mail: m.sani@fsskj.upsi.edu.my

Nur Haziyanti Mohd Khalid

Department of Exercise Science, Faculty of Sport Science and Coaching

Sultan Idris Education University

Tanjong Malim, Perak, Malaysia

Tel: 60-178-833-275 E-mail: nur.hazyanti@fsskj.upsi.edu.my

Nelfianty binti Mohd Rashid

Department of Exercise Science, Faculty of Sport Science and Coaching

Sultan Idris Education University

Tanjong Malim, Perak, Malaysia

Tel: 60-176-549-633Ｅ-mail: nelfianty@fsskj.upsi.edu.my 
Sadzali bin Hassan

Department of Exercise Science, Faculty of Sport Science and Coaching

Sultan Idris Education University

Tanjong Malim, Perak, Malaysia

Tel: 60-195-777-807Ｅ-mail: sadzali@fsskj.upsi.edu.my

\author{
Yusop bin Ahmad \\ Department of Exercise Science, Faculty of Sport Science and Coaching \\ Sultan Idris Education University \\ Tanjong Malim, Perak, Malaysia
}

Tel: 60-195-646-892Ｅ-mail: yusop@fsskj.upsi.edu.my

$\begin{array}{lr}\text { Received: March 26, } 2014 & \text { Accepted: May 8, } 2014 \quad \text { Published: May 30, } 2014 \\ \text { doi:10.5296/ijssr.v2i2.5714 } & \text { URL: http://dx.doi.org/10.5296/ijssr.v2i2.5714 }\end{array}$

\begin{abstract}
This study aims to analyze the level of physical fitness in the development of the National Standards of Physical Education. The study was conducted on 279 primary school boys age 10 years $(n=79), 11$ years $(n=94)$ and 12 years $(n=106)$ in five randomly selected schools in the state of Perak. FITNESSGRAM was used to test the level of physical fitness among subjects. This includes trunk lift, 90 degree push-ups, modified pull-up, back saver sit and reach and PACER. ANOVA analysis showed a significant difference in the level of physical fitness among the group of boys age 10, 11 and 12 years. Results showed that the $\mathrm{F}(2,0278)$ $=198.530, \mathrm{p}=0.000, \mathrm{p}<0.05$ was significant. The mean scores of boys age 12 years $(\mathrm{M}=57.52, \mathrm{SD}=4.18)$ was higher than the mean scores of boys age 11 years $(\mathrm{M}=52.40$, $\mathrm{SD}=3: 23)$ and mean scores of boys age 10 years $(\mathrm{M}=49.98, \mathrm{SD}=4: 21)$.
\end{abstract}

Keywords: Physical Fitness, National Physical Education Standards, FITNESSGRAM

\title{
1. Introduction
}

Physical education is one of the compulsory subject in primary schools in Malaysia. Primary goal of physical education is to help students become active through learning physical activity and fitness practices. To achieve these goals, the syllabus of physical education in elementary schools has seen increasing emphasis on physical fitness, motor skills sport skills and games. Physical Education Teaching and learning should provide oppourtunities for all students to improve the efficiency of motor mastery of basic skills and maintaining physical 
fitness. Students should already have a mastery of physical fitness and adequate knowledge to be applied in sports and games activities more effectively. Students at this level can already choose a favourite sport in co-curricular activities, sports and leisure in order to get satisfaction, fun, fitness and leisure, in accordance with the requirements of the National Education Philosophy.

To enable students to master and improve physical fitness, the Physical Education teaching and learning requires a strong and capable approach of producing a comprehensive education process intellectually, spiritually, emotionally and physically. Consequently, the PE teacher should produce an effective teaching and learning method to improve physical fitness by focusing on the various components of physical fitness. Physical education teaching and learning approaches that have established through testing and measurement standards and continuous and consistent with the school environment. However, to date no standard test that can be used on an ongoing basis at the school to assess the level of physical fitness and basic motor skills. Assessment should be conducted to determine the physical fitness performance and effectiveness of teaching and learning. Physical Education teachers need to understand the concept of test and measurement because it is a process of making decisions about student performance. Effective assessment requires a good testing procedure. Only a good testing procedure that is easy to use and can be understood will produce consistent test scores and reliability.

Study of Physical Education National Standards for Primary Schools was conducted to analyze the status of boys age 10,11 and 12 years in maintaining and enhancing the level of physical fitness. All assessment was based on the National Physical Education Standards set by the FITNESSGRAM. Teenagers who do not actively participate in physical activity have become a burden to the country and face the problem of overweight and obesity (Wolf, Manson, \& Colditz, 2002). Trends taking place today for those who do not actively participate in physical activity is expected to continue going forward. Most of the children are becoming less active in sports and physical education as a measure of the results of the Body Mass Index (BMI) among children is increasing towards overweight and obesity. Through formal physical education classes, students can be taught about the risks of the disease and how to actively engage in physical activity (Tappe \& Burgeson, 2004). This is easily done because the students are always in the school environment. Physical Education teachers should take full responsibility to educate students about physical activity and fitness. This study aims to produce a standard that is relevant and significant evaluation in accordance with what has been done by the developed countries. A National Physical Education Standards for Primary School in Malaysia will be introduced in all primary schools in Malaysia.

Mental and physical health problems are related to problems of composition and body fat will produce individuals who are not active, negative thinking and have low self physical description (Dietz, 1998). This situation would not benefit the country as having no source of competent workforce to drive future progress of the country. No serious evaluation process will indirectly affect as lowering the level of students' involvement in physical activity. No active involvement in physical activity will invite various diseases when these students grow 
older. Total time of sixty minutes or more a day is sufficient and appropriate for children to engage in physical activity (Corbin, Pangrazi, \& Le Masurier, 2004; NASPE, 2004). According to Erwin and Castelli (2008), about 23\% of children between the ages of 9 to 13 years do not take any part in physical activity in leisure time, while $39 \%$ indicated participation in physical activity outside of school hours. It is still the case, although the school has provided a variety of opportunities to engage in physical activity, especially during physical education class. Based on reports of worsening health problems among youth today, and coupled with the findings of the tendency of students to actively engage in physical activity for fun, then physical education was seen as having potential to be used as a subject in school curriculum. In Alabama alone there was a proposal to add 289 physical education teachers. While qualified professionals are also recommended that children 5-12 years of age must accumulate at least 60 minutes of moderate activity to engage in activities to the extent Vigorous daily (Corbin, Pangrazi, \& Le Masurier, 2004). Teachers rely on what they learned during the claimant and information obtained from reading the textbook, other than physical education experience they learned during childhood before (Schempp \& Graber, 1992).

The use of physical fitness test validity and reliability is very important because the main objective of physical fitness test is to keep fit for health and well-being (Corbin, Lovejoy, Steingard, \& Emerson, 1990). In the context of education, physical fitness testing experience for students and teacher effectiveness in performing these tests have implications for the quality and quantity of student learning in physical education. Physical Education teachers in various states have the option to choose the type of fitness test for their use. However, the existence of the influence of external factors unrelated to education in influencing the fitness test results cannot be dismissed. Therefore, education about fitness test is necessary for students to educate them about the importance of fitness and wellness, as well as a guide to physical activity participation in a more systematic and organized way.

Keating, Silverman and Kulinna (2002) state that children have the opportunity to learn physical fitness life patterns along with the development of their physical activity. Thus, the physical fitness test program has long been conducted in schools, but its implementation has not only according to the procedure that should (Keating, 2003). Sometimes, the fitness test is considered not a part of teacher education programs lead to less responsible for the results of the fitness test was conducted. Fitness testing in schools will be quite significant if the test can be used nationally as FITNESSGRAM (Keating, 2003). School, home and community should be involved in promoting a healthy lifestyle. FITNESSGRAM is a very good use and be aware that if made in school need to be careful to be compatible with the philosophy and purpose. Measure the effectiveness of physical fitness performance is dependent on the type and validity of selected tests. According to Baumgartner and Jackson (1970), based on the measurement of the performance scores of subjects should be used in a test. Michael and Kenneth (2005), has made a comparison of the level of fitness that involves cardiovascular endurance, body composition, muscular endurance and flexibility between student active in sports with regular students undergo physical education. 
Solmon (2003), in his study suggests five strategies to foster and enhance student participation in fitness activity through increased physical education class. First, make a deal with the students to strive to improve fitness in a given period of time. Second, train the students' and record the achievements from time to time so that progress can be seen as well as improvements to follow-up. Third, expose students to different types of fitness training so that students can make choices or variations in the training program. Fourth, relate theories related to physical fitness training programs or fitness activities so that students can apply what they have learned throughout life without confusion. Fifth, turn and vary teaching techniques so that students do not get bored and it is repeatedly drill for strengthening.

\section{Methodology}

Evaluation of Physical Education standards for assessing the level of physical fitness measured by FITNESSGRAM Cooper Institute for Aerobics Research, 2007). All assessment based on the National Physical Education Standards set by the National Association for Sport and Physical Education (NASPE, 2004).

\subsection{Subject}

A total of five primary schools in the state are selected randomly as school subjects. Total study subjects are a total of 279 primary school boys age 10 years $(n=79), 11$ years $(n=94)$ and 12 years $(\mathrm{n}=106)$ in five randomly selected schools in Perak

\subsection{Physical Fitness Test Instruments}

To test the physical fitness level of the tests used in this research is the trunk lift, 90 degree push-ups, modified pull- up, back saver sit and reach and PACER.

\subsection{Data Analysis}

The data collected were analyzed using SPSS for windows. Descriptive statistics (mean, standard deviation and percentages) were used to classify the percentage of 'pass' or 'fail' as compared to the reference criteria Physical Education National Standards (FITNESSGRAM, 2007; NASPE, 2004) to answer the question, to what extent the level of achievement of boys of primary school age 10,11 and 12 can maintain and improve physical fitness.

\section{Results}

Table 1 shows the results of a statistical analysis of the physical fitness level of boys age 10, 11 and 12 years of primary school. Analysis shows that a total of $77.2 \%(\mathrm{~N}=61)$ of boys age 10 years, $88.3 \%(\mathrm{~N}=83)$ of boys age 11 years and $62.3 \%(\mathrm{~N}=66) 12$-year-old male student has successfully passed the test based on the repeat run PACER Standards set by the FITNESSGRAM ${ }^{\circledR}$. 
Table 1. Criterion Reference PACER Test Compared FITNESSGRAM Standards

\begin{tabular}{|c|c|c|c|c|}
\hline \multirow{3}{*}{ Age } & \multicolumn{4}{|c|}{ Male } \\
\hline & \multicolumn{2}{|c|}{ Pass } & \multicolumn{2}{|c|}{ Fail } \\
\hline & $f$ & $\%$ & $f$ & $\%$ \\
\hline 10 Years & 61 & 77.2 & 18 & 22.8 \\
\hline 11 Years & 83 & 88.3 & 11 & 11.7 \\
\hline 12 Years & 66 & 62.3 & 40 & 37.7 \\
\hline
\end{tabular}

Table 2, shows that a total of $98.7 \%(\mathrm{~N}=78)$ of boys age $10,100.0 \%(\mathrm{~N}=94)$ of boys age 11 and $100.0 \%(\mathrm{~N}=106) 12$ year old male student who passed the test curl-up based on the number of repetitions set by Standard FITNESSGRAM.

Table 2. Criterion Reference Curl-Up Test Compared FITNESSGRAM Standards

\begin{tabular}{|c|c|c|c|c|}
\hline \multirow{3}{*}{ Age } & \multicolumn{4}{|c|}{ Male } \\
\hline & \multicolumn{2}{|c|}{ Pass } & \multicolumn{2}{|c|}{ Fail } \\
\hline & $f$ & $\%$ & $f$ & $\%$ \\
\hline 10 Years & 78 & 98.7 & 1 & 1.3 \\
\hline 11 Years & 94 & 100.0 & - & - \\
\hline 12 Years & 106 & 100.0 & - & - \\
\hline
\end{tabular}

Table 3, shows that a total of $82.3 \%(\mathrm{~N}=65)$ of boys age 10 years, $94.7 \%(\mathrm{~N}=89)$ of boys age 11 years and $96.2 \%(\mathrm{~N}=102) 12$ year old male student who passed the test based on the trunk lift measure the height defined by Standard FITNESSGRAM.

Table 3. Criterion Reference Trunk Lift Test Compared FITNESSGRAM Standards

\begin{tabular}{lccccc}
\hline & \multicolumn{3}{c}{ Male } \\
\cline { 2 - 4 } Age & \multicolumn{2}{c}{ Pass } & & \multicolumn{2}{c}{ Fail } \\
\cline { 2 - 5 } \cline { 5 - 6 } & $f$ & $\%$ & & $f$ & $\%$ \\
\hline 10 Years & 65 & 82.3 & & 14 & 17.7 \\
11 Years & 89 & 94.7 & & 5 & 5.3 \\
12 Years & 102 & 96.2 & & 4 & 3.8 \\
\hline
\end{tabular}

Table 4 , shows that a total of $100.0 \%(\mathrm{~N}=79)$ of boys age $10,100.0 \%(\mathrm{~N}=94)$ of boys age 11 and $100.0 \%(\mathrm{~N}=106) 12$ year old male student who passed the $90^{\circ}$ push-ups test based on the number of repetitions set by Standard FITNESSGRAM. 
Table 4. Criterion Reference Tubi $90^{\circ}$ Push-Up Test Compared FITNESSGRAM Standards

\begin{tabular}{lccccc}
\hline \multirow{2}{*}{ Age } & \multicolumn{3}{c}{ Pass } & & \multicolumn{3}{c}{ Male } \\
\cline { 2 - 3 } \cline { 2 - 5 } & $f$ & $\%$ & & $f$ & $\%$ \\
\hline 10 Years & 79 & 100.0 & & - & - \\
11 Years & 94 & 100.0 & & - & - \\
12 Years & 106 & 100.0 & & - & - \\
\hline
\end{tabular}

Table 5 shows that a total of $100.0 \%(\mathrm{~N}=79)$ of boys age $10,100.0 \%(\mathrm{~N}=94)$ of boys age 11 and $100.0 \%(\mathrm{~N}=106) 12$ year old male student who passed the modified pull-up test based on the number of repetitions set by Standard FITNESSGRAM.

Table 5. Criterion Reference Modified Pull-Up Test Compared FITNESSGRAM Standards

\begin{tabular}{|c|c|c|c|c|}
\hline \multirow{3}{*}{ Age } & & & \multicolumn{2}{|c|}{ Male } \\
\hline & \multicolumn{2}{|c|}{ Pass } & \multicolumn{2}{|c|}{ Fail } \\
\hline & $f$ & $\%$ & $f$ & $\%$ \\
\hline 10 Years & 79 & 100.0 & - & - \\
\hline 11 Years & 94 & 100.0 & - & - \\
\hline 12 Years & 106 & 100.0 & - & - \\
\hline
\end{tabular}

Table 6 , shows that a total of $87.3 \%(\mathrm{~N}=69)$ of boys age 10 years, $90.4 \%(\mathrm{~N}=85)$ of boys age 11 years and $99.1 \%(\mathrm{~N}=105) 12$ year old male student who passed the back saver sit and reach test based on the distance range set by Standard FITNESSGRAM.

Table 6. Criterion Reference Test Against Back Saver Compared FITNESSGRAM Standards

\begin{tabular}{lccccc}
\hline & \multicolumn{3}{c}{ Male } \\
\cline { 2 - 4 } Age & \multicolumn{2}{c}{ Pass } & & \multicolumn{2}{c}{ Fail } \\
\cline { 2 - 4 } \cline { 5 - 6 } & $f$ & 87.3 & & 10 & 12.7 \\
\hline 10 Years & 69 & 90.4 & & 9 & 9.6 \\
11 Years & 85 & 99.1 & & 1 & 0.9 \\
12 Years & 105 & & & $f$ & $\%$ \\
\hline
\end{tabular}

One-way ANOVA analysis showed a significant difference in the level of mastery of physical fitness among the group of boys age 10, 11 and 12 years. Results showed that the $\mathrm{F}$ $(2,0278)=198.530, p=0.000, p<0.05$ was significant. The mean scores of boys age 12 years $(\mathrm{M}=57.52, \mathrm{SD}=4.18)$ was higher level of physical fitness than the mean sciores of boys age 11 years $(M=52.40, S D=3: 23)$ mean scores of boys and 10 years $(M=49.98, S D=4: 21)$. 


\section{Conclusion}

Dowry, Welk, Rowe, Crotts, and Mclver (2006), showed that the higher the age, the higher student test scores on Pacer repeat. According to Zhang, Piwowar and Reilly (2000), a weak cognitive terms, would show low performance in terms of cardiovascular fitness, muscular strength and muscular endurance of a normal adolescence. This study was supported by Richard, Lesley, Catherine and Karen (2010), in a study to determine the effects of physical fitness on cognitive function. Knudson and Johnson (1998) describe the curl-up test is better suited to test the resilience of abdominal boys and girls in the period between 90 to 120 seconds. Kucharska, Szpala and Agnieszka (2010), indicates that Bent Leg Curl-Ups test is better from Curl-Up test straight away. This shows curl-up test is appropriate to look at the resilience of the abdominal muscles. Results of this study will spark new ideas to improve the process of testing, measurement and evaluation in physical education in primary schools. It is proposed that the National Standards of Physical Education Primary School used by all primary school physical education teachers to identify students' strengths and weaknesses in terms of motor skills and strategic knowledge of movement and physical fitness level. Elementary school physical education teachers can use the information level of physical fitness required to perform a variety of physical activities. Knowledge of these things help the teacher when planning instruction and learning strategies in Physical Education and extra-curricular activities and play school sports. National Standards of Physical Education (NASPE, 2004) was introduced with a more systematic testing procedure that can be used effectively by all teachers in Physical Education and in the Malaysian state of Perak. National Standards of Physical Education Primary School to provide information about the level of physical education in Malaysian primary school age. This information can be used by primary school teachers of Physical Education, Curriculum Planning Physical Education and Sports Science, Curriculum Development Centre and the Ministry of Education. Emphasis on physical fitness level should be a priority because it is the basis for motor development. Teachers also serve to impart knowledge in the field of expertise through a variety of teaching approaches to student learning that will be effectively gained.

\section{Acknowledgement}

The research is financed by Fundamental Research Grant Scheme, Malaysia Ministry of Education No. FRGS/KPT 2010-0029-106-02. Thanks to Research Management Center, Sultan Idris Education University for the opportunity to this research team.

\section{References}

American College of Sports Medicine. (2005). ACSM's Guideline for Exercise Testing and Prescription (7th ed.). Baltimore: Lippincott Williams.

Baumgartner, T. A., \& Jackson, A. S. (1970). Measurement for evaluation in physical education and exercise science (6th ed.). Dubuque, IA: Wm.C. Brown.

Corbin, C. B., Lovejoy, P., Steingard, P., \& Emerson, R. (1990). Fitness awards: Do they accomplish their intended objectives? American Journal Health Promotion, 4, 345-350. http://dx.doi.org/10.4278/0890-1171-4.5.345 
Corbin, C. B., Pangrazi, R. P., \& Le Masurier, G. C. (2004). Physical activity for children: Current patterns and guidelines. PCPFS Research Digest, 5(2), 1-8.

Dietz, W. H. (1998). Health consequences of obesity in youth: Childhood predictors of adult disease. Pediatrics, 101, 518.

Erwin, H. E., \& Castelli, D. M. (2008). National Physical Education Standards: A summary of student performance and its correlates. Research Quarterly for Exercise and Sport, 79(4), 495-505. http://dx.doi.org/10.1080/02701367.2008.10599516

FITNESSGRAM / Activitygram Test Administration Manual (4th ed) (2007). The Cooper Institute Dallas, Texas.

Hastie, P. A. (1998). Applied Benefits of the Sport Education Model. The Journal of Physical Education, Recreation \& Dance, 69. http://dx.doi.org/10.1080/07303084.1998.10605530

Keating, X. D. (2003). The current often implemented fitness tests in physical education programs: Problems and future directions. Quest, 55, 141-160. http://dx.doi.org/10.1080/00336297.2003.10491796

Keating, X. D., Silverman, S., \& Kulinna, P. (2002). Preservice teacher attitudes toward fitness tests and the factors influencing their attitudes. Journal of Teaching in Physical Education, 21, 193-207.

Kementerian Pelajaran Malaysia. (2002). Huraian Sukatan Pelajaran Kurikulum Bersepadu Sekolah Rendah. Pusat Perkembangan Kurikulum.

Knudson, D., \& Johanson, D. (1998). Analysis of three test durations of the nench trunk-curl. Journal of Strenght \& Conditioning Research, 12(3), 150-151.

Kucharska, R, Szpala, A., \& Agnieszka. (2010). Elektromyograpic Muscle Activity in Curl-up Exercise With Different Position of Upper and Lower Extremities. Journal of

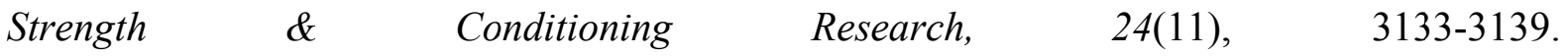
http://dx.doi.org/10.1519/JSC.0b013e3181ddb308

Mahar, M. T, Welk, G. J, Rowe, D. A, Crotts, D. J., \& Mclver, K. L. (2006). Development and Validation of a Regression Model to Estimate $\mathrm{VO}_{2}$ Peak From PACER 20-m Shuttle Run Performance. Journal of Physical Activity \& Health, 3(Suppl. 2), S34-S46.

Michael, B. W., \& Kenneth, P. H. (2005). Measurement and Evaluation of Cardiovascular Fitness Levels in California Youth: Response. Medicine \& Science in Sports \& Exercise, 4, 704.

National Association for Sport and Physical Education. (2004). Moving into the Future: National standards for physical education (2nd ed.). Reston: NASPE Publications.

Richard, W., Lesley, A. C, Catherine, L. D., \& Karen, L. N. (2010). American Journal of Health Education, 41(5), 284-291. http://dx.doi.org/10.1080/19325037.2010.10599155 


\section{Macrothink}

Schempp, P. G., \& Graber, K. C. (1992). Teacher socialization from a dialectical perspective: Pretraining through induction. Journal of Teaching in Physical Education, 11, 329-348.

Solmon, M. A. (2003). Student issues in physical education: Attitude, cognition, and motivation. In S. J. Silverman \& D. D. Ennis (Eds.), Student Learning in Physical Education (pp147-163).Champaign, IL: Human Kinetics.

Tappe, M. K., \& Burgeson, C. R. (2004). Physical education: A cornerstone for physically active lifestyles. Journal of Teaching in Physical Education, 23, 281-299.

Zhang, J., Piwowar, N., \& Reilly, C. J. (2000). Physical Fitness Performance of Young Adilts with and without Cognitive Impairments. Journal of Research in Health, 4(1), 46.

\section{Copyright Disclaimer}

Copyright for this article is retained by the author(s), with first publication rights granted to the journal.

This is an open-access article distributed under the terms and conditions of the Creative Commons Attribution license (http://creativecommons.org/licenses/by/3.0/). 